\title{
COMPARISON OF AL-SYATIBI AND THAHIR IBN ASYRIA'S THOUGHTS ON MAQASHID SHARI'AH
}

\author{
Bekti Cikita Setiya Ningsih \\ Pascasarjana UIN Sayyid Ali Rahmatullah Tulungagung \\ Jl. Mayor Sujadi No.46, Kudusan, Plosokandang, Kec.Kedungwaru, Kabupaten Tulungagung \\ Email: bekticikita@gmail.com
}

\begin{abstract}
This article will discuss the thoughts of two scholars in the field of maqashid sharia, namely Al-Syatibi as a classical scholar who studied maqashid sharia as an independent discipline until he got the nickname of the first teacher (muiallim awwal) by producing a work entitled al-Muwaffaqat fi Ushul al-Syariah. The second, Thahir ibn Asyur is a scholar who became the successor of Al-Syatibi in studying the maqashid sharia after the absence of maqashid sharia works for six centuries until he has dubbed the second teacher (muiallim tsani). According to Al-Syatibi, maqashid sharia is generally divided into two things, namely the legal establishment based on illat (ta'lil problem) and al-mashalih wa al-mafasid (benefit and damage) based on three levels of benefit, namely daruriyyat (primary maslahat), hajiyyat (secondary maslahat), and tahsiniyyat (tertiary maslahat). While Thahir ibn Asyur argues that maqashid sharia is divided into two things, namely maqashid sharia al-ammah and maqashid sharia al-khassah, thahir ibn Asyur's thinking is based on four things namely: al-musawah, al-fitrah, al-hurriyah and al-samahah. The purpose of this paper is compare the thoughts of the figures regarding maqashid sharia.
\end{abstract}

Keywords: Maqashid Sharia; Al-Syatibi; Thahir ibn Asyur

Abstrak: Tujuan dari penulisan ini ialah untuk mengkomparasikan pemikiran kedua tokoh mengenai maqashid syariah. Artikel ini akan membahas mengenai pemikiran Al-Syatibi sebagai tokoh ulama klasik yang mendalami maqashid syariah sebagai disiplin ilmu mandiri, hingga mendapatkan julukan guru pertama (muiallim awwal) dengan menghasilkan karya berjudul al-Muwafaqat $f i$ Ushul al-Syariah. Kedua, Thahir ibn Asyur ialah tokoh ulama yang menjadi penerus dari Al-Syatibi dalam mengkaji maqashid syariah setelah terjadi kekosongan karya maqashid syariah selama enam abad lamanya, hingga dijuluki sebagai guru kedua atau muallim tsani. Menurut Al-Syatibi, maqashid syariah secara umum dibagi menjadi dua hal, yakni penetapan hukum berdasarkan pada illat (masalah ta'lil) dan al-mashalih wa al-mafasid (kemaslahatan dan kerusakan) dengan berlandaskan pada tiga tingkatan kemaslahatan, yakni daruriyyat (maslahat primer), hajiyyat (maslahat sekunder), dan tahsiniyyat (maslahat tersier). Sedangkan Thahir ibn Asyur berpendapat bahwa maqashid syariah dibagi menjadi dua hal yakni maqashid syariah al-'ammah dan maqashid syariah al-khassah. Pemikiran Thahir ibn Asyur berlandaskan pada empat prinsip yakni al-musawah, al-fitrah, alburriyah, dan al-samahah.

Kata kunci: Maqashid Syariah; Al-Syatibi; Thahir ibn Asyur 


\section{Introduction}

Based on the terminology of sharia, maqashid can be interpreted as meaning and value used as a purpose or wants to be realized by Allah Swt. There is a role of mujtahid scholars who research sharia texts. ${ }^{1}$

The discussion of sharia maqashid according to the view of two figures, namely Abu Ishaq al-Syatibi and Thahir ibn Assyur which is close to bring benefits and avoid martyr hood. Imam Al-Syatibi is one of the classical scholars who studied his thoughts on sharia maqashid to have the nickname mu'allim awwal or the first teacher.

The discussion of sharia maqashid had experienced stagnation and problems of legal reason ushul fikih in designing the theoretical study of ushul fikih by packaging the concept of sharia maqashid. It took at least six centuries to end the return of the clerical figure who brought sharia maqashid into an independent discipline, namely Muhammad Thahir ibn Assyria. For his services, Thahir ibn Assyria was crowned as mu'allim tsani or the second teacher, after Al-Syatibi.

From the stagnating that occurred in the discussion of the discipline of maqashid sharia to reach six centuries, many things make a difference of thought between Imam AlSyatibi as a classical figure with the thought of Thahir ibn Assyria, who became a more modern figure in sharia maqashid thinking. It illustrated the difference between the background of the lives of the two figures and differences in educational background and supportive environment.

Based on this, the author explained the results of the thoughts of the two significant figures in the field of sharia maqashid by discussing sharia maqashid in general, the biography of the two figures, and the results of the thoughts of Imam Al-Syatibi and Thahir ibn Assyria. It is to conclude the similarities or differences of thought between the two figures regarding maqashid syariah.

\section{Maqashid Syariah General Concepts}

The word maqsad, according to Al-Yubi, has several meanings: 1.) a straight path, 2.) a handle, bringing something, 3.) fractions, 4.) balance, justice. In comparison, the word al-shari'ah means the primary source of life or the road to water. According to contemporary scholars, the understanding of sharia maqashid, namely Thahir ibn Assyria is the meanings and wisdoms that are considered shari'a' in all or most of his stages whose considerations are not considered limited to one particular type. Thus, the maqashid's characteristics of sharia, its general purposes, and meanings that are impossible not to consider in the stage. ${ }^{2}$

According to his language, maqashid Syariah means the purpose of sharia law. This shari'ah is a blessing to all humankind brought by the Prophet Muhammad (peace be upon him). It proves that every action done by every human being is healthy must have a purpose and purpose, especially the creator, Allah SWT, who wills, of course, everything determined has a purpose and purpose. The purpose in question has the term maqashid sharia in Islam. Khairul Umam, the quote from Ibn Qayyim Al-Jauziyah, states that the purpose of sharia is the benefit of slaves in the world and the hereafter.

\footnotetext{
2 Irham Sya'roni, "Maqashid Syariah Dalam Nalar Ilmiah Thahir Ibnu Asyur", Dscape UII, (2017-11), p. 6.
} 
According to the book of ushul fikih by Muhammad Abu Zahrah, who formulated the purpose of Islamic law, namely:

a. Build each individual to be a source of virtue for others and not be a source of hope for others. The way to achieve this goal is to worship narrated, such as prayer, fasting, and Hajj.

b. Uphold justice in society, both fellow Muslims and non-Muslims, as Allah says in Q.S. Al-Maidah verse 8, which means: "O you who believe you should be those who always uphold (the truth) because of Allah, be just witnesses. Moreover, do not be at all times your hatred of a people, encouraging you to be unjust. Be fair because justice is closer to piety. Furthermore, fear Allah, Surely Allah is all-knowing what you are doing.". 3

c. Realizing good, that is, the primary purpose of Islamic law, is essential.

The Qur'an has explained the source of law in Islam, and only Allah knows the content or purpose of His words. The Qur'an revealed to the Prophet Muhammad (peace be upon him) was intended to be used as a benchmark for his life.

According to Al-Syatibi, sharia maqashid has three groups of understanding patterns, namely:

1. The opinion of scholars who consider that maqashid sharia is an abstract thing can not be known except through the instructions of the precise pronunciation of Allah Swt.

2. The class of scholars who know maqashid sharia by not taking the approach of zahir lafal. It is based on that maqashid

\footnotetext{
3 https://tafsirweb.com/1892-quran-surat-al-maidahayat-8.html
}

sharia must be related to the notions of pronunciation.

3. The scholars who combine the two approaches of consideration of meaning in a form that does not trigger the destruction of the understanding of zahir pronunciation and also does not cause damage to the content of illat so that sharia continues to run.

From the three thoughts of the above scholars, several ways can be done to find out sharia maqashid, among others.:

a. It was analyzing the pronunciation of prohibitions and orders, namely by analyzing the pronunciation that falls into the category of amr and memorization, which is the category of al-naby, which is contained in the Qur'an and hadith clearly before linking to other problems. That is, returning to the meaning of orders and prohibitions in essence.

b. The study of orders (illat al-amr) and prohibition (al-nayi) analyzes the pronunciation that falls into the category of commands and pronunciations categorized as prohibitions. Illah is divided into two; namely, the law is written clearly in the verse or hadith that must follow what is written. In contrast, the illah is not written can be known where the people submit it to Allah Swt (tawaqquf) because Allah Swt knows best all the purposes of the law.

To analyze al-Sukut al-Syar'iyyah is to understand sharia maqashid in the development of Islamic law, namely understanding legal issues that are not mentioned by al-Syar'i where this legal problem has a positive impact on life.

The purpose of sharia maqashid delivered by Imam Al-Syatibi is "At once not the sharia is made except by realizing human beings 
both in the world and in the hereafter and preventing the existence that will befall them."

Islamic law aims to create the benefit of life for humans by avoiding evil and bringing good. The benefit in question is undoubtedly a public benefit that is not partial and essential, then must be oriented to five things: religion, soul, property, reason, and descendants. Islamic law is intended to realize the benefits from the things that have been mentioned such as religion, soul, property, reason, and descendants have a priority level of need, namely: religion, soul, property, reason, and descendants have a priority level of need, namely: daruriyyat, hajiyat, dan tabsiniyat.

The need of the daruriyyat level is to maintain and realize the needs that are very essential or essential to the life of Muslims. The need of daruriyyat translates as primary need. The second level of need is hajiyat (secondary need) for human life, but this need is intended to provide convenience and eliminate difficulties and difficulties in mukallaf life. Then the third is tahsiniyat or tertiary needs that should exist to beautify life even without the fulfillment of the tahsiniyat life will not cause difficulties or damage. ${ }^{4}$ The essence of the purpose of sharia is the benefit of daruriyyat; this makes the fulfillment of human needs that are daruriy is a demand for benefits that can not be bargained anymore. The needs that are daruriy as already mentioned earlier consist of 5 things, namely'

1. Hifzud-din means maintaining and maintaining religion.

2. Hifzun-nafs means take care and nurture the soul.

3. Hifzul-aqlmeans take care and nurture the mind

4 Amrullah Hayatudin, Ushul Figh: Jalan Tengah Memahami Hukum Islam, (Jakarta: Amzah, 2019), p. 209.

${ }^{5}$ Amrullah Hayatudin, Ushul Figh..., p. 210.
4. Hifzun-nasl means take care and nurture descendants

5. Hifzul-mal means take care and nurture possessions.

\section{Biography of Abu Ishaq Al-Syatibi}

The classical cleric is full name Abu Ishaq Ibrahim bin Musa bin Muhammad al-Lakhmi al-Syatibi, an influential figure in Islamic legal thought that focuses on sharia maqashid. Imam Al-Syatibi is from Granada, Spain. He is a mujtahid, hafidz Quran, tafsir, jurisprudent, hadith, language, and ushiliyah. Imam Syatibi is also known as an accomplished philosopher of Islamic law based on the Maliki school. Personal biodata about Imam Syatibi is very minimal because not many people review in detail this figure's life. He died and was buried in Granada on Tuesday, 8 Shaban 790 Hijri or in $1388 \mathrm{AD}$. The region of Granada is a center of scientific activity because the establishment of the University of Granada during the reign of Sultan Muhammad V Al-Ghani Billah was also the heyday of Muslims in Granada. The young $\mathrm{Al}$-Syatibi was entirely obtained in the capital of the kingdom of Nashr; Granada was the last bastion of Muslims in Spain at the time.

Imam Al-Syatibi obtained many advantages during his education in the region of Granada because he found many great teachers in his field. The teachers had various backgrounds; some were natives of the Granada region, many teachers from Al-Syatibi were immigrants and eventually became scholars in the region.

The teachers who had taught knowledge to Al-Syatibi and were also natives, namely ${ }^{6}$ :

\footnotetext{
6 Muslimin Kara, "Pemikiran Al-Syatibi tentang Maslahah dan Implementasinya dalam Pengembangan Ekonomi Syariah", Assets: Jurnal Akuntansi dan Pendidikan, Vol. 2 No.2, 2012, p. 19.
} 
1. The most famous scholar in the field of Arabic and Qira'at was named Abu Fakhar al-Biriy. From this scholar, Al-Syatibi learned about Qira'at and Nahwu. Abu Abdullah Muhammad Al-Biri is one of the scholars who is a scholar in language and Nahwu Arabic (Shaykh Al-Nuhat). In $754 \mathrm{H}$ or $1353 \mathrm{AD}, \mathrm{Al}-$ Syatibi had the experience of living with the teacher to explore the knowledge until the end of the teacher died.

2. A scholar in the field of nahwu named Abu Ja'far al-Syaquri

3. A mufti in Granada named Abu Sa'id bin Lub. From this scholar, Al-Syatibi learned about jurisprudence.

4. A famous mufassir, Abu Abdullah AlBalnisity. From this scholar al-Syatibi menimba ilmu about tafsir and other ulumul quran.

The teachers who contributed to teaching knowledge to Imam Al-Syatibi, who was an immigrant in Granada.

1. A famous scholar in the field of jurisprudent and ushulfikih named Abu Abdullah Syarif al-Tilmisani. As the name implies, it comes from Tilmisan, an area in Algeir.

2. A scholar from Tilmisan named Abu Abdullah al-Muqiriy. He is a scholar with his work Qawa'id al-Fiqh al-Muqiriy.

3. One of the leading Maliki scholars in Granada was Ibn Marzuq al-Khatib.

4. A great scholar in the field of ushul fikih named Abu Ali al-Zawawiy. From this scholar, Al-Syatibi studied a lot of ushul fikib; even al-Syatibi openly quoted his opinion.

After Imam Al-Syatibi had adequate knowledge, he then developed his knowledge

\footnotetext{
${ }^{7}$ Muslimin Kara, "Pemikiran Al-Syatibi...”, p. 21.
}

by teaching to the next generations. Among the disciples of Imam Al-Syatibi, were: Shaykh Faqih Abu Abdullah al-Bayani, Abu Jafar al-Qassar, Abu Abdullah al-Majariy, Abu Yahya ibn Asim, and Abu Bakr ibn Asim. The teaching materials provided by Imam Al-Syatibi are works that he has coraled himself and have become his masterpiece until now. ${ }^{8}$

During his lifetime, Imam Al-Syatibi produced great works, among others:

a. First, the book that explains Al-Syatibi's commentaries on the book al-Khulasa alAlfyyah by Ibnu Malik entitled Al-Khulashah fi al-Nahwi fi Asfari Arba'ati Kibar.

b. Second, there is al-Syatibi's most crucial work entitled Al-Muwafaqat. This book explains the science of ushul fikih and introduces the concept of maslahah and maqashid according to Al-Syatibi.

c. The third is a book that describes buying and selling in Bukhari's sahih book entitled Kitab al-Majalis.

d. Fourth, the book explaining literature and the art of composing in Arabic is entitled Kitab al-Ifadat wa al-Insyadat.

e. Fifth is the book of Unwan al-Ittifaq fi' Ilmi al-Isytiqaq.

f. Sixth, Al-Syatibi created various fatwas and also Arabic verses entitled the book of Ushul al-Nahwi.'

\section{Biography of Muhammad Thahir ibn Asyur}

Muhammad At- Thahir Ibn 'Assyur was one of the sharia maqashid scholars born in La Marsa north of Tunis, Tunisia. Tunisia is one of the Islamic countries in mainland North Africa where $40 \%$ is the desert of the

\footnotetext{
${ }^{8}$ Muslimin Kara, "Pemikiran Al-Syatibi...", p. 22.

${ }^{9}$ Nabila Zatadini, "Konsep Maqashid Syariah...”, p. 115.
} 
Sahara, and the rest is a fertile land. The Barbarians were the first ethnic people to inhabit Tunisia and are predicted to have lived in the interior of North Africa since the old stone age. The majority of Muslims in Tunisia are Sunnis, with 97\% of all Muslims there and the rest are Khawarij Ibadiyah. Muhammad Thahir Ibn Assyria died in 1296 $\mathrm{H} / 1879 \mathrm{AD}$ in Tunisia.

Thahir ibn Assyria has lived in the clerical environment, so that he has received education from scholars in Tunis. His family is of native Andalusian descent who migrated to Tunisia. The lineage of Thahir ibn Assyria is a combination of nobility (power) and scholars. His grandfather and father were Supreme Court Justices, while grandfathers from the maternal path were Grand Vizier. From the side of ibn Assyur's extended family, this encouraged him to create the thought of sharia maqashid as outlined in his works. ${ }^{10}$

At a young age, Thahir ibn Assyria had memorized the Qur'an; at the age of seven years $(1886 \mathrm{H})$, he entered Zaitunah college and pursued primary education for seven years, after which he continued to senior level at the same institution. Passion for seeking knowledge and earnestness in learning and positive support from fathers, maternal grandfathers, and teachers. Thahir ibn Assyria is a critical person in accepting the teachings of the courses he took, not limited to critical on a problem. However, he often compares cases that he thinks are interesting. Some of the courses that Thahir ibn Assyur took were: balagah, nahwu, mantik, lugah, kalam science, fikih, ushul fikih, hadith, sirah, date, and faraid.

\footnotetext{
${ }^{10}$ Fuat Hasanudin, "Review Buku Maqashid Syari'ah Ibn Asyur: Rekonstruksi Paradigma Ushul Fikih", ABHATS: Jurnal Islam Ulil Albab, 2020, Vol. 1, No. 1, 2016, p. 3.
}

Some of the positions that had been held by Thahir ibn Assyria, among others. ${ }^{11}$ :

1. He served as chief justice (Qodhi qudhot al-Malikiyah) in 1332H/1913 A.D.

2. Thahir ibn Assyria had also been an adviser to the government in the religious section.

3. In 1932 AD became Shaykh of Islam AlMaliki and Shaykh Al-Zaitunah.

4. Once also a teaching council in AlZaitunah produced many great scholars, one of whom was none other than Thahir ibn Assyria's son named Muhammad AlFadhil ibn Assyria.

\section{Abu Ishaq al-Syatibi's Thoughts about Maqasid al-Syari'ah}

Imam al-Syatibi based his entire ushul theory on inductive principles to build the epistemology of Islamic law. The presence of al-Syatibi as the first teacher (mu'allim awwal) in the discipline of maqashid al-sharia took almost six centuries to continue the baton of this science relay in the hands of Ibn 'Assyria, who was later called the second teacher (mu'allim tsani).

The existence of legal problems and stagnation of ushul fikih reason in line with the times motivated Imam Al-Syathibi to design the theoretical study of ushul fikih, especially by packaging the maqashid conception of sharia to be his principal study, as reviewed in his monumental work, al-Muwafaqat. Because of these intellectual services, al-Syatibi was crowned as the founder of maqashid sharia (mu'assis 'ulum al-maqashid al-syariah).

In addition, Al-Syatibi succeeded in making maqashid part of the science of ushul fikih.

\footnotetext{
${ }^{11}$ Indra, "Maqashid al-Syariah...", p. 174.
} 
There is a common ground between the theory of Islamic law and the philosophy of Islamic law. According to Al-Syatibi, sharia law has the primary purpose of the benefit of the people. As a basis for understanding Islamic law, there are 3 (three) levels of benefit, namely, daruriyyat (maslahat which is essential), hajiyyat (supporting maslahat), and tahsiniyyat (maslahat refinement/ accessories). ${ }^{12}$

The first position is the need for the daruriyyat level to maintain and realize the essential or basic needs for the lives of Muslims. The need of daruriyyat translates as an immediate need. If the position of need is not fulfilled, the salvation of humankind will threaten both in this world and hereafter. For example, the implementation of five-time prayer and Ramadan fasting.

The second position is the need for hajjyat, which is a secondary need, where if it is not realized, it does not threaten its safety but will have difficulties. Islamic law eliminates all these difficulties. The existence of the law of rukhshah (leniency), as explained by Abd al-Wahhab Khallaf, is an example of Islamic sharia concern for this need. ${ }^{13}$

Maqashid tahsiniyat is to perfect both previous maqashids, including the perfection of regular habits and noble morals. (Moh. Toriquddin,2014:35). This third need or refinement supports improving the dignity of one's life in society and before Allah Swt within reasonable limits and obedience. ${ }^{14}$

12 Sidik Tono, "Pemikiran dan Kajian Teori Hukum Islam Menurut Al-Syatibi”, Jurnal Al-Mawarid, Edisi XIII, (2005), p. 106.

13 Usman Betawi, "Maqhasid Al-Syariah sebagai Dasar Hukum dalam Pandangan Al-Syatibi dan Jasser Auda", Jurnal Hukum Responsif FH UNPAB, Vol. 6, No. 6, 2018, p. 37.

${ }^{14}$ Moh. Toriquddin, "Teori Maqashid Syari'ah...", p. 35.
The five benefits of daruriy are as follows:

1. The first is to preserve religion or hifzuddin. Religion plays a vital role in human life, according to the view of Islam. Religion has the essence of human existence because a man without religion is like someone who walks without light at night. Human nature, according to Islam, is religion. The human need for religion can be caused by the fundamental principle problem of human needs. Given the importance of religion in human life, there is a guideline in Islam, namely the principle of hifzuddin. To be more clear about this hifzud-din, then there are three underlying priorities, namely:

a. Maintaining religion (hifzud-din) is the main priority or daruriyyat, namely maintaining and carrying out religious obligations that fall into the primary or main priority, such as performing prayers five times. If a person ignores his prayer, threatened religious needs.

b. Maintaining religion (hifzud-din) is the priority of hajj, namely to avoid difficulties implementing religious provisions, then the permissibility of jama' and qashar prayers when traveling. This aims to facilitate or alleviate a person's difficulties when traveling without threatening the existence of religion.

c. Maintaining religion (hifzud-din) in the priority of tahsiniyat, namely following the guidance of religion and completing the implementation of the duty of a servant to his God while upholding the dignity of man. Just like it is circumcised for a man to wear clean and good clothes and use fragrances when performing Friday prayers. This means not only because a man does not wear good clothes and uses fragrances 
and then does not go to the mosque to perform Friday prayers where here Friday prayers are the main priority or daruriyyat for a man.

2. Hifzun-nafs, or maintaining the soul, ranks second in the opinion of the majority of scholars pioneered by Imam Al-Ghazali, as well as the thought of Ibn Taymiyyah, who argued, "corruption sometimes in religious affairs and sometimes in world affairs. The greatest corruption in world affairs is to kill souls without rights. Therefore, murder is one of the great sins, after the greatest corruption is unbelief in matters of religion." Hifzun-Nafs, based on its priorities, are as follows::

a. At the daruriyyat level, humans meet the primary needs of food to survive. If this need is not met, it can threaten the human body.

b. The priority of Hajiyat, humans, are obtained to eat delicious food and drinks. If it is not done, it does not cause a threat to human life.

c. Tingkat tahsiniyat, diberlakukannya cara makan dan minum sesuai dengan etika kesopanan. Hal ini tidak mempersulit dan mengancam jiwa manusia.

3. Next is hifzal-aql, or maintaining reason. This theory existed even before Islam came with teachings that valued the function of reason. Then the teachings of Islam consider the importance of the function of the reason for human existence. Not only to appreciate, the teachings of Islam also protect the mind from factors that can be destructive. Like the Word of Allah almighty found in Q.S. Al-Isra' verse 70, which means: "And indeed We have honored the sons of Adam, We transported them on land and in the sea, We gave them sustenance from the good, and We verified them with a perfect advantage over most of the creatures We have created." 15

Hifzal-Aql, based on priority level:

a. The first is that at the daruriyyat level, humans are forbidden to drink alcoholic beverages. This is not good and has terrible consequences with the breakdown of reason.

b. The second is the level of hajj, where there is a recommendation to demand knowledge. It is not life-threatening, but it can complicate life if it is not done.

c. At the tahsiniyat level, humans ignore unsuitable news, such as ghibah or gossip.

4. Nurturing offspring or hifzal-nasl focuses on the importance of official marriage in Islamic teachings, aiming to channel sexual instincts and desires with halal and sah. Maintaining nasab clarity and preserving it is the goal of hifzal-nasl. Islamic teachings also strongly prohibit adultery that can have an impact on the vagueness of a child. It can also be a disgrace to sociology and $\sin$ for religion for pregnant women out of wedlock because of adultery. Islam establishes a way that can protect honor and offspring. Hifzal-Nasl, according to the level of priority is as follows::

a. At the daruriyyat level, humans are not allowed to commit adultery and are encouraged to marry.

b. In the level of hajj, humans are allowed to set dowry and the right of talaq from the husband.

c. The third is the level of tabsiniyat, which is human beings are advised to

15 https://tafsirweb.com/4674-quran-surat-al-israayat-70.html 
ask (khitbah) or walimah in the marriage procession.

5. Hifzal-mal or maintaining property is a way of Islamic teachings to protect the property of a servant so that halalan toyyiban. Hifz al-mal, based on its priority level, namely:

a. At the daruriyyat level, humans are allowed to collect the property in the way it is narrated. There is a prohibition on taking other people's property in a way that is violated by sharia.

b. At the level of Hajj, humans are advised to buy and sell with a good contract.

c. At the tahsiniyat level is a provision to stay away from fraud in the ethics of business.

\section{Muhammad Thahir ibn Asyur;s Thoughts about Maqasid al-Syari'ah}

Thahir ibn Assyria's view of sharia maqashid is broader than that of its predecessor, the way it does is to develop a discussion in the field of sharia maqashid that discusses various issues of muamalat (maqashid al-Syariah al-khassah), including family law, laws and regulations, use of property, testimony and others. ${ }^{16}$ The thought of Thahir ibn Assyria had reaped the pros and cons among scholars because of his idea to leave the study of ushul fikih, which he thought would only cause differences in furu' (fikih).

According to Thahir ibn Assyria, four elements are the basis in the foundation of the building of sharia maqashid that must be considered in formulating Islamic law, namely al-fithrah, al-musâwah, al-samâhah, and al-hurriyah. The description of Thahir ibn Assyria's thoughts on the formulation of Islamic law is as follows:

${ }^{16}$ Irham Sya'roni, "Maqashid Syariah Dalam Nalar Ilmiah Thahir Ibnu Asyur", Dscape, UII, 2017-11, p. 8.
1. Al-fitrah can be interpreted as creation (khilqah). The definition of al-fitrah is a system that Allah almighty creates in every creature. Human creation means everything that is created in man, including reason and body, both bathin and end. It is based on Q.S. Al-Rum verse 30, which means "Then put your face straight to the religion of Allah; Allah created man according to it. There is no change in God's grace. It is a straight religion, but most people do not know....".

In the opinion of Thahir ibn Assyria, fitrah can be classified into two parts: fitrah aqliyah and fitrah nafsiyah. Understanding aqliyah fitrah or clear logic is the fitrah of logic that leads to the substance in the essence of something. Man has the right to uphold noble values and truth, but various factors and external or external influences can distract from that basic form. Human nature hates things like misinformation, destructive environments, and deviant behavior that is accustomed and pursues what is consciously shunned.

2. Al-Musawah can mean that every Muslim occupies the same or equal position before Islamic law. There is no difference in the face of Islamic law. This is based on a fundamental principle, namely Islam as a religion of fitrah. Islam merges all its adherents in a forum of global brotherhood contained in the word of Allah Swt in Q.S. Al-Hujurat verse 10 reads, "The believers are truly brothers...". According to Thahir ibn Assyria, equality by fitrah is equality and equal treatment of all individuals despite their differences. The differences do not affect each other's contributions to realize the collective benefit.

3. Al-Samahah means tolerance or generosity; a moderate attitude praised in peace according 
to Thahir ibn Assyria means there is in the middle dimension between the two extreme poles that are too taklif or too tolerance. Thahir Ibn Assyria based the wisdom of tolerance in Islamic sharia by making Islamic sharia in harmony with the fitrah embedded in the human soul to be readily accepted. Al-Syatibi stated that several propositions containing the elimination of difficulties and narrowness in religious matters had reached the level of qath' ${ }^{\prime 17}$.

4. Al-Hurriyah What means freedom is the right to act according to oneself as desired without hindrance. Freedom is divided into several aspects, among others: words, deeds, and creeds, deeds with the conclusion that every Muslim under the auspices of the Islamic government is free to do everything that is allowed in sharia according to the provisions and rules of sharia, not justified a person burdened more than that.

In general, the study of the propositions of the Qur'an and partial cases show that the general purpose of the study of Islamic law is to maintain the order or system of human life and the preservation of that benefit. It is by maintaining the benefit of the man himself, which includes the maslahah of reason, deeds, and nature in which he lives. Thus, it can be said that the general rule in Islamic sharia is to reject mafsadah and bring maslahah. This can be achieved by improving the human condition and rejecting its existence. Every deed that is in the community must be realized and maintained. On the contrary, all acts that hinder the benefit and invite forgiveness must be avoided and eliminated. ${ }^{18}$

\footnotetext{
${ }^{17}$ Ainol Yaqin, "Revitalisasi Maqashid Al-Syari'ah...", p. 329.

${ }^{18}$ Ainol Yaqin, "Revitalisasi Maqashid Al-Syari'ah...", p. 337.
}

\section{The Comparison of Al-Syatibi and Thahir ibn Asyur's Thoughts}

Maqashid sharia, according to al-Syatibi's view, is guided by two general theories, namely the establishment of law based on illat (ta'lil problem) and al-mashalih wa al-mafasid (welfare). Al-Syatibi's thoughts on sharia maqashid dwell on sacred texts concerning religious subjects (kulliyah studies) and sacred texts that discuss religious details (juz'iyyah). According to Al-Syatibi, the establishment of the law is aimed at achieving the benefit of the people in this world and the hereafter, in the present and the future.

While Thahir ibn Assyria as a contemporary scholar, developed thought and perfected the concept of sharia maqashid from his predecessor, Al-Syatibi. Thahir ibn Assyria argues that there are two main theories of sharia maqashid, namely maqashid al-syariah al-ammah (the purpose and objectives of sharia related to the benefit and interests of the ummah in general), and maqashid al-syariah al-khassah (objectives of sharia that concern particular matters). ${ }^{19}$

Based on the development and refinement made by Thahir ibn Assyria to maqashid sharia from the thoughts of his predecessor. $\mathrm{He}$ argued that the independence of sharia maqashid as a discipline in itself is essential for the renewal of the science of ushul fikih by using a way of sorting between absolute propositions (qat'iy) with relative propositions (zanniy). Thahir ibn Assyria concluded four basic epistemology maqashid such as religious instinct (al-fitrah), tolerance (al-samahah), egalitarian (al-musawah), and freedom of action (al-hurriyat). ${ }^{20}$

\footnotetext{
19 Irham Sya’roni, "Maqashid Syariah Dalam Nalar Ilmiah Thahir Ibnu Asyur”, Dscape, UII, (2017-11), p. 15.

${ }^{20}$ Irham Sya’roni, "Maqashid Syariah...”, p. 9.
} 


\section{Conclusion}

From the description above, conclusions can be drawn about sharia maqashid. According to the perspective of Imam AlSyatibi, if all the law is examined in sharia, then everything is made for mashalih al-'ibad (human benefit) as the basis of understanding Islamic law. Based on the thought of Imam Al-Syatibi, there are three levels of benefit, namely daruriyyat (primary maslahat), hajiyyat (secondary maslahat), and tahsiniyyat (tertiary maslahat). While according to Thahir ibn Assyria, four elements are the basis in the foundation of sharia maqashid building that must be considered, namely al-fithrah, al-musâwah, al-samâhah, and alhurriyah.

\section{References}

Aziz, Muhammad. "Reconstruction of Maqashid Shari'ah Perspective Muhammad Thahir Ibn 'Assyria: Efforts to Re-Discuss Sharia with Reality", Jurnal Hukum Islam, Vol. 17, No. 2, (2019).

Betawi, Usman. "Maqhasid Al-Syariah sebagai Dasar Hukum dalam Pandangan Al-Syatibi dan Jasser Auda", Jurnal Hukum Responsif, Vol. 6, No. 6, (2018).

Effendi, Orien.: Kontribusi Pemikiran Maqasid Syariah Thahir Ibnu Asyur Dalam Hukum Islam”, Bilancia: Jurnal Studi Ilmu Syariah dan Hukum, Vol. 14, No. 2 (2020).

Ghazali, Muhammad ibn Muhammad al-, AlMustashfâ Min 'Ilm al-Ushûl, Beirut: Dar al Fikr, t.t., Jilid II

Hasanudin, Fuad. "Review Buku Maqashid Syari'ah Ibn Asyur: Rekonstruksi Paradigma Ushul Fikih", ABHATS: Jurnal Islam Ulil Albab, 2020, Vol. 1, No. 1, (2016).

Hayatudin, Amrullah. "Ushul Fiqh: Jalan Tengah
Memahami Hukum Islam", Jakarta: Amzah, 2019.

Indra, Maqashid Asy-Syariah Menurut Muhammad At-Thahir Bin Asyur, Tesis, UIN Sumatra Utara, Medan, 2016.

Kara, Muslimin. "Pemikiran Al-Syatibi tentang Maslahah dan Implementasinya dalam Pengembangan Ekonomi Syariah", Assets: Jurnal Akuntansi dan Pendidikan, Vol. 2 No. 2, (2012).

Khatib, Suansar. "Konsep Maqashid Al-Syari'ah: Perbandingan Antara Pemikiran Al-Ghazali Dan Al-Syathibi”, Jurnal Ilmiah Mizani, Vol. 5, No. 1 (2018)

Musa, Sayid Muhammad, al-Ijtihâd wa Madâ Hâjâtinâ Ilaihi fi Hâdza al-'Ashr, Mesir: Dâr al-Kitab al-Haditsah, 1992.

Nadwi, Ali Ahmad al-. al-Qawâid alFiqhiyyah, Damaskus: Dâr al-Qalam, 1991, Cet. ke-2

Sholikah. "Pengembangan Maqasid al-Syari'ah PerspektifThahir Ibnu `Asyur”, International Journal Ihya' 'Ulum al-Din, Vol. 21, No. 1 (2019).

Syàroni, Irham. "Maqashid Syariah Dalam Nalar Ilmiah Thahir Ibnu Asyur”, Dscape UII, 2017.

Syalabi, Muhammad Musthafa, Tảlîl al-Ahkâm, Kairo: Dâr al-Nahdhat al-Arabiyyah, 2011. Syatibi, Abu Ishaq al-. Al-Muwâfaqât fi UshûlalAhkâm, Beirut: Dar al-Fikr, t.th., Juz II, III Syatibi, Abu Ishaq al-. Al-Muwâfaqât fi Ushûl al-Syarîah, disunting oleh Abdullah Darrâz, Mesir: Maktabah al-Tijariyah al-Kubra, t. th., Jilid I

Tono, Sidik. "Pemikiran dan Kajian Teori Hukum Islam Menurut Al-Syatibi”, Jurnal Al-Mawarid, Edisi XIII, (2005).

Toriquddin, Moh. "Teori Maqashid Syari'ah PerspektifAl-Syatibi”, de Jure: Jurnal Syariah dan Hukum, Vol. 6, No. 1, (2014).

Yaqin, Ainol. "Revitalisasi Maqashid Al-Syari' ah 
dalam Istinbath Hukum Islam: Kajian atas Pemikiran Muhammad Al-Thahir Ibnu 'Asyur', ASY-SYIR'AH: Jurnal Ilmu Syariah dan Hukum, Vol. 50, No. 2, (2016).
Zatadini, Nabila. "Konsep Maqashid Syariah Menurut Al-Syatibi dan Kontribusinya dalam Kebijakan Fiskal", Al-Falah: Journal of Islamic Economics, Vol. 3, No. 2, (2018). 